\title{
Albanian Migration to the U.S.A. Geo-Historical Research Contributions
}

\author{
Bilal Draçi \\ Pal Nikolli \\ University of Tirana, Faculty of History and Philology, Geography Department \\ E-mail: bilal_draci@yahoo.it
}

Doi:10.5901/mjss.2014.v5n2p441

\begin{abstract}
Typology of the reasons for migration, dominated by forced migration (mainly wars) and labor migration, intensified by the late nineteenth century and early twentieth century. Massive migration periods are: the Roman period (less documented), Middle Ages (XIV-XV century); period between the Albanian national revival and independence; periods during world wars and the period after the fall of Communism (1990). While migrations tipizohen today because of work and living better. Varies according to geography and world developments, especially regional developments (Balkan Mediterranean). Characteristics of today's migration are becoming almost universal. Accurate statistical estimates are difficult (from 150 thousand to 500 thousand) because of its complex integrations, sources of social organizations and illegal migration in certain periods. Selection of emigration countries related to geographical proximity (Greece, Italy); cultural and linguistic proximity; historical ties; economic developments; accessability; regulatory incentives to migration policies, making phenomenon spontaneous and problematic since to the country of origin up to the destination. Referring to official statistics $95 \%$ of immigrants are located in Europe.
\end{abstract}

Keywords: immigration; ethnicity; territory; culture; generation; location;

\section{Introduction}

In general literature and statistics about early migrations Albanian been limited and must be treated carefully. But some generalized conclusions can be considered valuable from a historical and geographical aspect, referring to the Albanian and foreign authors as:Nagi D 1988; King R; Gruber, S. (2003); de Rapper, G. (2000); Psimmenos and Georgoulas 2001; Lianos, T. (2001); Labrianidis, L. and Hatziprokopiou, H. (2005); Zonzini, L. (2005); Carletto, G., Davis, B., Stampini, M. and Zezza, A. (2004); Bonifazi, C. and Sabatino, D. (2003); Vickers, M. and Pettifer, J. (1997); Sjöberg, Ö. (1994); Konica F. 1923; Orgocka 2005; Tirtja M (1999); Misja, V.; Bërxholi A; Barjaba K; Vullnetari J; etj. Studies are regional and they are focused on host countries such as Italy, Greece, and mainly U.S.A.

Nowadays on the different causes, processes and consequences of this phenomenon, it is a revival of studies on migration, identity, ethnicity, integration and development, environment, etc., in the context of globalization and conflict in the world. Working methods for the realization of the study are: the study of literature and theoretical studies in this field; direct observations in the field, questionnaires and interviews in the Albanian-American community; estimates of official statistics and other datas from the web-site, associations, publications etc..., graphic and cartographic methods. On this basis, comparative evaluations are done and "analogical" (with other communities in the U.S.A); analysis and geohistorical estimates.

\section{Geo-historical Evaluations of the Albanian Immigrations in America}

Years before the period 1945-50, the main countries of Albanian migrations were Latin American countries and the U.S.A as part of the European migratory flow at this time. First Albanian migrant in the U.S.A, with lost identity, and documented as such, belongs to 1876 which later migrated to Argentina. Koli Christopher (Nicholas Christopher), from Katund village of Korca, in 1886, with 16 other Albanians, were reported as the first migrants settled in the U.S.

There are some opinions than previously individuals and small ethnic groups of Albanians emigrated to the U.S.A. Those involved in large migratory groups named "Balkan", or in other ethnic groups as Turkish, Greek, Romanian, Serbian, etc.., and not Albanian, making controversial their number. Before the 1920s, immigrants dominated by group "Tosk Orthodox" from Korca and surrounding areas of southern part of the country. They accounted only $20 \%$ of the 
country's population. There have been several waves of mass migration which by the time, the causes and consequences can be divided into three periods:

\subsection{First period. From the beginnings to 1945 developed in 2 stages:}

The first stage, from early migration until 1925, was developed with the following features:

- Immigrant groups dominated by young men (100 burra/10 women) (Faik Konica, 1923)

- Their number increased continuously reaching 25-30 thousand Albanians (Jane Jurgens, 1995; Faik Konica 1923).

- motives were mostly economic and occasionally with politica and military character

- Immigrants had conviction of temporary migration, temporary enough to stay as to help their families. They had the desire to return to Albania after the declaration of independence of the country's This immigration had individual character.

- Settlements were located and scattered throughout Boston. Later they were distributed in the northeastern states. Migrants lives in poor housing conditions, at the "guest house", barracks (about 10 people) and in the "coffeebar". Only from middle of 1910 began to organize into associations (according to newspapers of the time), unlike other greater communities

- immigrants had no professional preparation for the new american industries and for this they were a cheap workers without many rules, (they came mainly from suburban and rural areas of Albania)

- as first generation, these immigrants included mainly in the lower socio-economic category (with income under 10 thousand \$ / capita / year, without social positions etc

- end of the first decade of years 1900 marks the beginnings of nationalism: Albanian leaders were free from political and religious of Turkish and Greek pressure; economic life was improved, social status increased, new political factors developed in favor of small countries; albanians believed to support the U.S. in their objectives. Establishment of the Albanian Orthodox Church from Albanian Bishop Noli had a major role not only in terms of religious and social cohesion but also in the growth of national consciousness, identity and ethnicity. Thus began the social organization and was established the first Albanian colony of Masacustsit as the higher national politic institution.

- Social life at the beginning was poor and later focused on religious institutions and much later in the family. It was published the first albanian newspapers.

- After the declaration of independence, (1912) a significant number of immigrants went back to Albania (up 20 thousand) to contribute to economic and political development of the country.

- "Disappointment" with the political (wars, riots, etc. feudal power) economic and social development during the first period, the final return of immigrants brought to America at $90 \%$.

- This was a massive return (with documents and illegally), and family level leading to the abandonment of many villages. The number of immigrants is estimated about 50 thousand.

- This massive return modified family goals, Albanian arrangements, american institutions and lifestyle. On this basis:

- instead of "Hostels" and collective settlements albanians bought or rented house with a target for new life style as the american, unlike before where albanians were suspicious for everything that was American.

- Church political activities lost their importance against primary of educational and cultural activity or charity activity.

- $\quad$ during this period began an intensive process of application for citizenship by $6 \%$ (1920) to 30\% (1930) and a rapid increase in demand for this purpose.

- Increased economic level, the promotion of entrepreneurship and business, and general welfare

- $\quad$-increased of level of education (college degree to $35 \%$ ) and professionalism in the secondary and tertiary sectors.

- over $50 \%$ of migrants were involved in middle class of American society (with over 30 thousand $\$$ / capita ( year)

- began to identify new quality of the second generation of settlers (holding of two languages, american models of cultural behavior, mixed marriages to the extent of 35-50\%, private businesses, ethnicity falling)

- increased of social status of Albanians in social activities (youth organizations, women, business, etc.) 
and appeared problems of assimilation, acculturation or cultural pluralism.

\subsection{Second Period 1945-1990 (communist regime) with two stages:}

During this period, communist regime isolated and controlled the country. In this context controlled also migration especially immigration. From the beginning of the communist regime, had illegal immigrations for political and economic reasons and this period was characterized by Albanian-European immigrants to America (through Italy, Greece, Serbia, Turkey, etc)

During the stage, 1965-1990, the closing of churches, collectivization etc. caused

Illegal immigrations as well as increased demand for family reunions (renounced Albanian citizenship around 1000 persons). Some of the features of this period are as follows:

- In numerical terms, claimed over 70 thousand Albanian immigrant, excluding Albanian territories immigrants.

- Number of immigrations in this period was small. (22 persons-1983, 32-1984-persons, 45 persons-1985: 62 persons - 1987, 88 persons -1989 - Jurgens J-2000, English-Americans, Washington DC). At this stage should be included also Albanian immigration outside Albanian ethnic lands.

- Reduction of immigration flows during the second period weakened the regeneration, transfusion, and reinforce the ethnic and cultural of Albanian community, losing and mixed the value of ethnic identity.

- Grew up socio-economic status where the majority of Albanians entered in the middle class over $55 \%$.

- Albanian private businesses grew up with over $30 \%$. The employees were mainly in the services sector, small and medium trade, construction, service industries, forestry, etc.

- Unlike north European and English immigrants who settled in small towns and in rural areas, albanians as part of the South East European migration, they settled in towns but not concentrated in the neighborhood, for more job opportunities and housing.

- During this period shaped the second and third Albanian-American emigrants generation with features defined as: less and less use of the Albanian language in the church and in the family associations; performing of mixse marriages ( $10 \%$ of first generation, $50 \%$ of second generation and $78 \%$ of third generation); increase the level of education (10\% of first generation, $75 \%$ of second generation and $35 \%$ of third generation); decline of religious practice and ethnic activities; pattern of American life style without ethnic preferences.

- While the second generation appear ambiguous (mixed) by ethnicity. Third generation display with more highlighted elements to assimilation and cultural pluralism.

- Albanian immigrants in America as a small and distributed ethnic group without concentrations (neighborhood centers, etc.) can be characterized in terms of assimilation as "cultural pluralism" group, where ethnic groups retain some aspects of their culture but also actively participate or have a dominant role in the culture and not in the acculturation (this happens more in large groups imposing their own culture to the smallest groups). (Dennis N. Nagy, 1989).

\subsection{The third period after 1990}

Restoring of historical ties, 50 years of isolation, chaotic situation of political and economic developments at the beginning of the 90 s, realization of the "American dream", as country of economic prosperity, freedom and development opportunities, were some of the main reasons (push-factor) of Albanian emigration to the U.S.A

Some of immigration routes were through embassies, through status of political refugee; various visa programs; illegal ways; asylum requests (over 500 requests / year; in this way have also benefited 65 diplomats from 2001 to 2005); family reunions, other cooperation programs of exchange.

In this period can be distinguished several stages migratory flows that reflect the economic situation and democratization and integration processes.

- Period of years 1990 - 1992, was recognized as the period of wave of mass immigration where about 300000 people migrated through embassies and mostly in illegal ways to neighboring and Europe countries.

- Period of years 1992- 1996 recognized as a period of economic stabilization efforts and the growth of border controls, where emigration took place with lower rates.

- the period of years 1996-1997, known as the period of the collapse of the pyramid schemes where Albanians lost their savings, followed by a political and economic chaos that led to the emigration of over 100000 


\section{Albanians}

- Kosovo war (1999) was followed by a massive forced migration of the population from Serb repression towards the U.S.A. and European countries. A part of Kosovars during the war in Kosovo (1999) granted the status of refugee. (Source: Forum 2015. Diaspora and Migration Policies in Kosovo, Riinvest Institut. Prishtinë Decembër 2007).

- Years after 2001 were known as the period of political-economic consolidation that marked the beginning of the fall until the end of the mass emigration of the population. This is due to the liberalization policy of visa regime with EU countries (2011)

Provision of the data about the number of Albanian emigrants to U.S.A, since 1990 has been a problematic process, so we are based on the following main sources:

- Official statistics of the U.S.A. government and Albanian, with numerical data close to each other, 113661 (year 2000) and 150000 (v.2005).

- Associations and organizations of the Albanian community, with about 250000 immigrants in 1989 and 500 000 Albanian ethnic immigrant of Albania, Kosovo, Macedonia, Montenegro, Serbia, etc.

- references and studies of different authors (Barjaba 2005; Orgocka 2005; Vullnetari 2008; King 2008; Jurgens 2000; Lehman 2000; Tirtja 1999; Nagi 1988; Trix 2001 etj.) and other sources, mostly informal, newspapers, website.

- In these statistics are not including illegal immigrants, students and individuals in various study programs, persons with temporary visas who have "Social Security Number".

- Based on the calculation of the rate of emigration with about 3-4000 people / year through the "Green Card", results that Albanian immigrants in the U.S.A. are about 180 thousand. About three-quarters of immigrants entered through the "Diversity Visa Program," through American lottery, (76\% v. 2000) etc.

- Also need to mention the fact that Albanians are included in the group of four countries in the world most favored by the program. (Turkey has benefited 100/vet until 1960; 200-300 after 1960 and 4000 in our days. and so did the other communities have .. Kaya. Ilhan, 2005, identity and space: the case of Turkish Amerikans). Albanian emigrants - American admissions requirements are growing "naturalization", from 350 in 1996 to 4000, in 2006.

\section{Map of the Albanian Migration to the U.S.A. Some Geographical Considerations}

Placement of Albanian immigrants in the U.S. are plotted as follows:

Graphic.1: Albanian migration by country

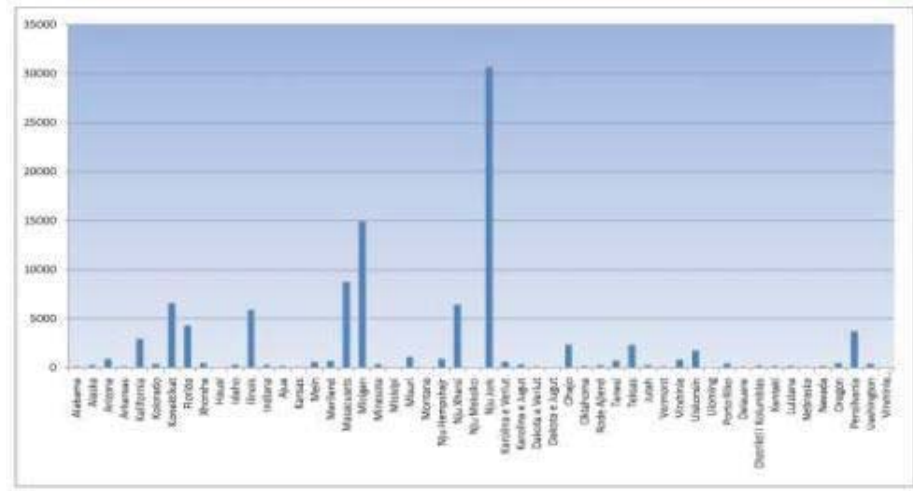

- Albanians are located in every U.S.A state.

- The largest concentration of Albanians is in the north eastern of U.S.A (New York, Massachusetts, Connectica, Pennsylvania etc. This affects ethnicity and its development as cultural pluralism.

- lower concentration found in the Midwest region which dominates assimilation

- In western regions (California) and South (Texas) have average concentration with emigrants, while the high 
concentration is in Florida

- Boston or the "Mecca of Albanians" and the Albanian-American cultural center possesses an ethnic force in the development process of cultural pluralism.

- New York is the economic epicenter not only by the number of emigrants but also by the number of the business and assets of the Albanian emigrants.

- Tends of population movements toward west and southern

Figure. 1. Map of Albanian immigrants in the U.S.A

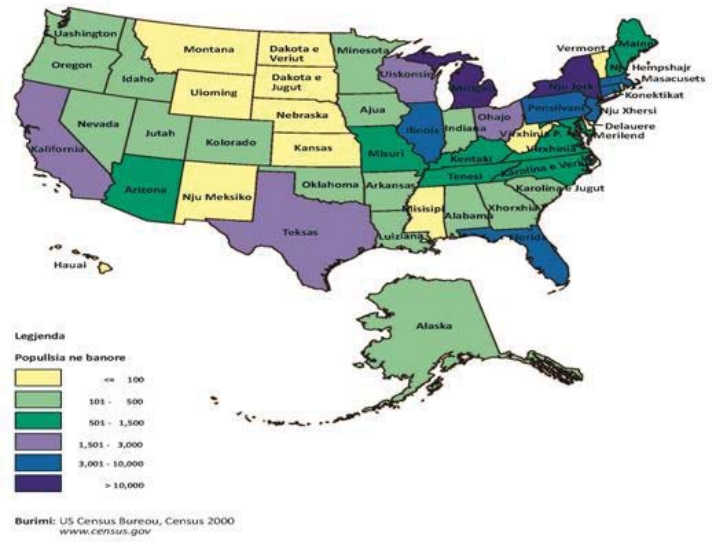

\section{Some Results, Discussion and Recommendations}

Based on the above information concluded that:

Albanians constitute:

- Smaller numerical group (less than $1 \%$ of ethnic groups and communities in the U.S., compared with small countries like Slovenian, Croatian, Macedonian, Estonian, Lithuanian, etc.).

- Later group in terms of time of Europeans emigration (end of the nineteenth century and early twentieth century).

- More diffuse group between communities in the U.S.A. They live in all U.S.A. states. These and other factors related to the Albanian national identity, ethnicity, social cohesion, integration etc.

Including ethnic territories, history and typology of migrations, the emigration period is divided into four stages:1early migration until 1945 for work purposes; 2 - politic migration under communist regime (1945 to 1990); 3 - migration of albanians outside ethnic territories, started in 1960 for national, political and economic purposes; 4 - migration after 1990 for economic and political reasons.

Some other findings are:

- Albanian immigrant in USA are more educated and integrated than Albanian immigrants in Europe.

- Albanian Americans are not fanatics in practicing and declaring the religious (results that in 1908 there were 45 thousand Orthodox, 25-35 thousand Muslims in 1913, 1350 Catholics in Boston Bronx and New York, Bektashi sect founded in Michigan 1954. (http / / www.everyculture.com / multi / A-Br / EnglishAmericans.html)

- Interruption of the flow of migration durind 1945-1990 weakened Albanian ethnicity and identity. After 1990 is created the opportunity to regenerate the migratory flows but with problems of integration between generations.

- After 1990 Albanians are chartered by the U.S.A government with migration policy. So have received Green Card lottery or other visa programs around 3-4000 persons / year

- Until 1910 the first Albanian immigrants have not had a real sense of their identity and ethnicity.

- There is small theoretical literature on these issues as well as practical studies about ethnic groups. Less so for Albanians and with geographic focus of this phenomen.

- In small groups often ethnicity was hidden and was focus to other larger groups. This has happened in the 
Albanian community.

- Large groups have "pressed" small groups but they it happened less in America. Policies "Melting Pot" as the merger integration into American style with processes of acculturation, cultural pluralism, assimilation is a process integration and Albanians even a little more for economic reasons and better lifestyle.

- Albanian ethnicity is developed in traditional areas with a large number of immigrants mainly the last decade.

\section{Recommendations}

There are few studies on Albanian immigration and on Albanian immigration in U.S.A. Therefore the geographic focus of the research is important in these directions:

- What are the most appropriate models of conservation, development and integration of the Albanian-American community? What are the most appropriate theoretical models of their development and their integration?

- What are the relationships between generations, social classes, ethnicity link

- Who should support ethnicity? Institutions, organizations or religion?

- Measurement and evaluation of ethnicity, its trends

- What are the effects of mixed marriages, the size of ethnic groups.

- Which are the ethnicity trends between generations?

- Do Albanians live assimilation, acculturation or cultural pluralism. Which is more appropriate?

- What effects does globalization and new technologies on ethnicity?

- Studies need to be periodically updated with issues which are very dynamic

\section{References}

Barjaba, K. (2000) Contemporary patterns in Albanian emigration. South-East Europe Revieë, 3(2): 57-64.

Barjaba, K., Dervishi, Z. and Perrone, L. (1992) L'emigrazione albanese: spazi, tempi cause. Studi Emigrazione, 29(107): 513-38.

Carletto, G., Davis, B., Stampini, M. and Zezza, A. (2004) Internal Mobility and International Migration in Albania. Rome: FAO, ESA Working Paper 04-13.

Carletto, G., Davis, B., Stampini, M. and Zezza, A. (2006) A country on the move: international migration in post-communist Albania. International Migration Review, 40(4): 767-85.

INSTAT (2004a) Migration in Albania. 2001 REPOBA. Tirana: Instituti i Statistikës.King, Russell, Skeldon,

Julie Vullnetari. Albanian Migration and development: State of the art revieë. IMISCOE Working Paper Nr. 18. September 2007

King, R., Mai, N. and Dalipaj, M. (2003) Exploding the Migration Myths: Analysis and Recommendations for the European Union, the UK and Albania. London: The Fabian Society and Oxfam.

King, R. and Vullnetari, J. (2003) Migration and Development in Albania. Brighton: University of Sussex, Development Research Centre on Migration, Globalisation and Poverty, Working Paper C5.

Nagi, D. (1988) The Albanian-American Odyssey. A Pilot Study of the Albanian Community of Boston, Massachusetts. New York: AMS Press.

Nazi, F. (2000) Balkan diaspora I: the Albanian-American community, in William, J. B. (ed.) Kosovo. Contending Voices on Balkan Interventions. Grand Rapids, MI and Cambridge: William, B. Eerdemans Publishing Company, 132-35.

Orgocka, A. (2005) Albanian highly skilled women in the US, in King, R., Mai, N. and Schwander-Sievers, S. (eds) The New Albanian Migration. Brighton: Sussex Academic Press, 13953.

Psimmenos, I. and Georgoulas, S. (2001) Migration pathëays: a historic, demographic and policy revieë of the Greek case, in Triandafyllidou, A. (ed.) Migration Pathëays: a Historic, Demographic and Policy Review of Four European Countries. Brussels: European Commission, IAPASIS Project Report, 38-62.

Ravenstein, Ernst Georg (1885/1889): 'The laws of Migration'. Journal of the Statistical Society of London 42(2), pp. 167-235 \& Journal of the Royal Statistical Society 52 (2), pp. 241

Ronald \& Julie Vullnetari (2008): 'Internal and International Migration: Bridging theTheoretical Divide', Paper prepared for the IMISCOE 'Theories of Migration and Social Change Conference, St. Anne's College, Oxford, 1-3 July 2008.

Tirta, M. (1999) Migrime të shqiptarëve, të brendshme dhe jashtë atdheut (vitet '40 të shek.XIX-vitet '40 të shek.XX). Etnografia Shqiptare, 18.

US Department of Homeland Security (2006) Yearbook of Immigration Statistics: 2005. Washington DC: US Department of Homeland Security, Office of Immigration Statistics.

US Department of Homeland Security (2007) Yearbook of Immigration Statistics: 2006. Washington DC: US Department of Homeland Security, Office of Immigration Statistics. 